\title{
HUBUNGAN KECUKUPAN ZAT GIZI DAN KONSUMSI MAKANAN PENGHAMBAT ZAT BESI DENGAN KEJADIAN ANEMIA PADA LANSIA
}

\author{
Putri Rahmah Alamsyah', Dini Ririn Andrias² \\ 1,2Departemen Gizi Kesehatan, Fakultas Kesehatan Masyarakat, Universitas Airlangga \\ Kampus C Unair Jalan Mulyorejo Surabaya \\ Email: Putri_rahma1059@yahoo.com
}

\begin{abstract}
ABSTRAK
Bertambahnya usia akan menyebabkan tubuh mengalami perubahan-perubahan seperti anatomi, fisiologi, ekonomi, dan sosial. Hal tersebut akan menyebabkan perubahan pada pola konsumsi. Tujuan penelitian ini adalah untuk mengetahui hubungan kecukupan zat gizi dan konsumsi makanan yang mendukung dan penghambat penyerapan zat besi dengan kejadian anemia pada lansia. Penelitian ini merupakan penelitian cross sectional yang dilakukan di Kelurahan Airlangga, Kecamatan Gubeng, Kota Surabaya pada bulan Maret-April 2016. Besar sampel adalah 73 lansia. Pengambilan sampel dengan cluster random sampling dan besar sampel pada masing-masing klaster (posyandu) ditentukan secara proposional sesuai dengan jumlah lansia yang ada pada tiap posyandu lansia. Pengumpulan data kadar hemoglobin menggunakan alat Easy Touch, sedangkan data asupan dan kecukupan zat gizi menggunakan teknik wawancara Food Recall $2 \times 24$ jam. Data frekuensi konsumsi makanan pendukung penyerapan zat besi dikumpulkan dengan menggunakan Food Frequency Questioniare. Hasil penelitian menunjukkan ada hubungan tingkat kecukupan asam folat $(p=0,002)$, konsumsi kopi $(p=0,045)$, dan teh $(p=0,028)$ dengan kejadian anemia pada lansia. Sebaliknya tidak ada hubungan antara tingkat kecukupan protein, zat besi, vitamin $\mathrm{C}$, vitamin $\mathrm{B}_{12}$ dengan kejadian anemia pada lansia. Penelitian ini merekomendasikan Pemberian Makanan Tambahan (PMT) yang cukup kandungan zat besinya atau dapat mendukung penyerapan zat besi bagi lansia.
\end{abstract}

Kata kunci: anemia, enhancer dan inhibitor zat besi, lansia

\begin{abstract}
Getting older causes many alterations in the human body such as alterations in anatomy, physiology, economy, and social. This condition can cause a disturbance at the consumption pattern. The purpose of this research is to analyze the relation between nutrients adequacy, consumption patterns of foods which support or inhibit iron absorption and anemia status among elderly. This cross sectional research was held in Airlangga Sub - district, Gubeng District of Surabaya from March until April 2016. Sample was 73 elderlies. The research used cluster random sampling method, which sample was taken from each cluster (Posyandu) proportionally based on the number of elderly at elderly health care (Posyandu). The research collected hemoglobin level data using Easy Touch tool, nutrient intake using $2 \times 24$ hours Food Recall method and frequency of consumption of foods which support or inhibit iron absorption by using Food Frequency Questionnaire. The result of the research shows that there is a relation of adequacy of folate intake $(p=0.002)$, coffee consumption $(p=0.045)$, and tea consumption $(p=0.028)$ with anemia status among elderly. On the other hand, there is no relation between the adequacy level of protein, iron, vitamin $C$, and vitamin $B_{12}$ with anemia status among elderly. The research recommends supplementary food program to elderly with foods which may provide iron or iron absorption enhancer.
\end{abstract}

Keywords: anemia, iron enhancer and inhibit, elderly

\section{PENDAHULUAN}

Jumlah lansia (lanjut usia) di Indonesia terus mengalami peningkatan, hal ini disebabkan oleh penurunan angka fertilitas penduduk dan peningkatan usia harapan hidup. Berdasarkan Kemenkes RI tahun (2013) provinsi yang mempunyai persentase lansia tertinggi diatas $10 \%$ yaitu Jawa Timur (10,40\%) dengan jumlah lansia tertinggi di Kota Surabaya yang berada di Kecamatan Gubeng (42,19\%). Anemia adalah suatu keadaan rendahnya kadar eritrosit di dalam darah yang ditandai dengan menurunnya kadar 
hemoglobin. Anemia merupakan suatu penyakit yang paling sering dialami oleh lansia. Kemenkes RI pada tahun 2013 menemukan prevalensi penyakit tidak menular pada usia lanjut di Indonesia antara lain anemia $(46,3 \%)$, penyakit hipertensi (42,9\%), penyakit sendi $(39,6 \%)$, serta penyakit jantung dan pembuluh darah (10,7\%). Lansia usia 65-74 tahun di Indonesia yang mengalami anemia sebesar 34,2\% dan lansia usia $>75$ tahun sebesar 46\% (Kemenkes RI, 2013).

Anemia pada lansia disebabkan karena kurangnya tingkat konsumsi zat gizi seperti protein, zat besi, vitamin $\mathrm{B}_{12}$, asam folat, dan vitamin $C$. Kekurangan zat gizi dapat dipengaruhi oleh perubahan karakteristik lansia antara lain fisiologi, ekonomi, sosial dan penyakit penyerta pada lansia seperti penyakit degeneratif, kronik, dan infeksi yang akan berpengaruh terhadap pola makannya. Selanjutnya berpengaruh pula terhadap rendahnya konsumsi zat gizi yang menyebab lansia mengalami anemia (Ping, 2012).

Teh dan kopi mengandung tanin yang dapat mengikat mineral antara lain zat besi. Pada teh hitam terkandung senyawa polifenol yang apabila teroksidasi akan mengikat mineral seperti zat besi, zink, dan kalsium. Oleh sebab itu teh hitam merupakan inhibitor yang paling kuat menghambat penyerapan zat besi (Marcitelli, 2010). Berdasarkan penelitian yang dilakukan oleh Thankachan (2008) menunjukkan bahwa lansia yang mengonsumsi 1 cangkir teh dapat menurunkan absorbsi besi sebanyak 49\% dan mengonsumsi 2 cangkir sehari dapat menurunkan absorbsi besi sebesar $67 \%$.

Apabila lansia tidak diperhatikan tingkat kecukupan zat gizi serta lansia masih banyak mengonsumsi teh dan kopi akan menyebabkan lansia lebih mudah mengalami anemia. Lansia yang mengalami anemia lebih mudah terkena penyakit, memperlambat proses penyembuhan sehingga berdampak terhadap status kemandirian lansia.

Lansia yang mengalami anemia berisiko mengalami peningkatan mortaitas dan morbiditas dua kali lipat dibandingkan lansia yang mempunyai kadar hemoglobin normal. Lansia yang berusia diatas 85 tahun yang mengalami anemia mempunyai risiko kematian lima kali lebih besar mengalami kematian dibandingkan lansia yang tidak anemia (Nakashima, 2012).

Berdasarkan hal tersebut, penelitian tentang anemia pada lansia perlu dilakukan. Penelitian ini bertujuan untuk mengetahui hubungan tingkat kecukupan zat gizi dan konsumsi makanan penghambat penyerapan zat besi dengan kejadian anemia pada lansia.

\section{METODE}

Penelitian ini merupakan penelitian observasional dengan desain cross sectional. Populasi dalam penelitian ini adalah semua lansia yang bertempat tinggal di Kelurahan Airlangga, Kecamatan Gubeng, Kota Surabaya.

Perhitungan sampel menggunakan rumus Lemeshow (1997) dengan nilai $\alpha=95 \%$ berdasarkan studi pendahuluan di Kelurahan Airlangga, dengan nilai mean Hemoglobin 9,5 g/dl sehingga diperoleh responden sebanyak 73 orang yang didapatkan dengan metode Cluster Random Sampling dengan cluster adalah posyandu lansia. Pengambilan sampel ditentukan secara proposional sesuai dengan jumlah lansia yang ada pada masingmasing posyandu.

Teknik pengumpulan data dilakukan dengan wawancara. Data asupan zat gizi diperoleh melalui wawancara dengan kuesioner Food Recall $2 \times 24$ jam yang kemudian diolah menggunakan Nutrisurvey. Untuk mengetahui kecukupan zat gizi, asupan zat gizi protein dibandingkan dengan $\mathrm{AKG}$ (Angka Kecukupan Gizi) dan untuk zat gizi lain dibandingkan dengan konversi Estimated Averange Requiments (EAR) yang disesuaikan dengan usia dan jenis kelamin.

Faktor konversi pada laki-laki usia $19 \rightarrow 65$ tahun untuk zat besi 1,3, vitamin C 1,2 sedangkan vitamin $B_{12} 1,2$, dan asam folat sebesar 1,25. Faktor konversi pada perempuan usia $51 \rightarrow 65$ tahun untuk zat besi sebesar 1,6, untuk vitamin $\mathrm{B}_{12}$ 1,6 , asam folat 1,25 dan vitamin $\mathrm{C} 1,3$ untuk usia 51-65 tahun sedangkan usia $>65$ tahun 1,2 untuk vitamin $\mathrm{B}_{12}$, konversi ini akan dikalikan dari hasil perhitungan Nutrisurvey. Apabila hasil perhitungan zat gizi lansia lebih rendah dari Estimate Average Requements (EAR) akan dimasukkan dalam katagori kurang dan apabila tingkat konsumsi zat 
gizi diatas Estimate Average Requements (EAR) maka dimasukkan dalam katagori cukup (Gibson, 2005).

Data frekuensi konsumsi yang menghambat penyerapan zat besi seperti kopi dan teh dikumpulkan dengan menggunakan form Food Frequency Questionare (FFQ). Frekuensi konsumsi baik harian, mingguan maupun bulanan semuanya dikonversi menjadi mingguan. Kadar hemoglobin diperiksa dengan alat Easy Touch, pengambilan darah dilakukan di Posyandu lansia, darah yang diambil dari ujung jari dengan peralatan steril dan dilakukan oleh tenaga perawat yang sudah terlatih.

Analisis hubungan tingkat kecukupan zat gizi dengan kejadian anemia dianalisis menggunakan analisa Fisher's Exact Test dikarenakan jumlah sampel terlalu kecil. Analisa Hubungan konsumsi kopi dan teh dengan kejadian anemia dianalisis menggunakan analisa Spearman dikarenakan data konsumsi zat gizi berbentuk rasio dengan distribusi tidak normal.

\section{HASIL DAN PEMBAHASAN}

Berdasarkan Tabel 1, proporsi terbesar lansia berusia $>65$ tahun sebesar $72,6 \%$ dan yang mengalami anemia sebesar $94,5 \%$. Nilai median kadar hemogobin lansia dalam penelitian ini 10,32 $\mathrm{mg} / \mathrm{dl}(7,3-13,3 \mathrm{~m} / \mathrm{dl})$. Presentase anemia pada lansia di Kelurahan Airlangga, Kecamatan Gubeng lebih tinggi dari prevalensi anemia nasional yaitu sebesar $46,3 \%$.

Tabel 2 menunjukkan bahwa secara umum kecukupan zat gizi pada lansia masih banyak yang kurang. Dalam penelitian ini ada kecenderungan lansia yang kurang dalam mengonsumsi zat gizi mempunyai presentase mengalami anemia lebih tinggi dibandingkan lansia yang cukup mengonsumsi zat gizi.

Hasil penelitian menunjukkan masih banyak lansia yang belum dapat memenuhi tingkat kecukupan protein. Persentase kejadian anemia lebih tinggi pada lansia yang mempunyai tingkat kecukupan protein kurang dibandingkan pada lansia yang cukup mengonsumsi protein. Penelitian yang dilakukan Hurellm (2010) tidak menemukan hubungan bermakna antara tingkat kecukupan protein dengan kadar hemoglobin. Konsumsi makanan sumber protein hewani khususnya

Tabel 1. Distribusi Status Anemia pada Lansia di Kelurahan Airlangga Kecamatan Gubeng Kota Surabaya

\begin{tabular}{lcc}
\hline Karakteristik Lansia & n & Presentase (\%) \\
\hline Usia & & \\
60-65 tahun & 20 & 27,4 \\
$>65$ tahun & 53 & 72,6 \\
Total & 73 & 100,0 \\
Kejadian Anemia & & \\
Anemia & 69 & 94,5 \\
$\quad$ Tidak Anemia & 4 & 5,5 \\
Total & 73 & 100 \\
\hline
\end{tabular}

Tabel 2. Hubungan Tingkat Kecukupan Zat Gizi dengan kejadian anemia pada Lansia di Kelurahan Airlangga, Kecamatan Gubeng, Kota Surabaya, 2016

\begin{tabular}{|c|c|c|c|c|c|c|c|}
\hline \multirow{2}{*}{ Kecukupan Zat Gizi } & \multicolumn{2}{|c|}{ Anemia } & \multicolumn{2}{|c|}{ Tidak Anemia } & \multicolumn{2}{|c|}{ Total } & \multirow{2}{*}{ P-value } \\
\hline & $\mathbf{n}$ & $\%$ & $\mathbf{n}$ & $\%$ & $\mathbf{N}$ & $\%$ & \\
\hline \multicolumn{8}{|l|}{ Kecukupan Protein } \\
\hline Cukup & 4 & 80 & 1 & 20 & 5 & 100 & 0,252 \\
\hline Kurang & 65 & 95 & 3 & 5 & 68 & 100 & \\
\hline \multicolumn{8}{|l|}{ Kecukupan Zat Besi } \\
\hline Cukup & 12 & 92,3 & 1 & 7,7 & 13 & 100 & 0,552 \\
\hline Kurang & 57 & 95 & 3 & 5 & 60 & 100 & \\
\hline \multicolumn{8}{|l|}{ Kecukupan Vitamin C } \\
\hline Cukup & 2 & 100 & 0 & 0 & 2 & 100 & 0,893 \\
\hline Kurang & 67 & 94,4 & 4 & 5,6 & 71 & 100 & \\
\hline \multicolumn{8}{|l|}{ Kecukupan Vitamin $B_{12}$} \\
\hline Cukup & 6 & 100 & 0 & 0 & 6 & 100 & 0,704 \\
\hline Kurang & 63 & 94 & 4 & 6 & 67 & 100 & \\
\hline \multicolumn{8}{|l|}{ Kecukupan Asam Folat } \\
\hline Cukup & 0 & 0 & 2 & 100 & 2 & 100 & 0,002 \\
\hline Kurang & 69 & 97,2 & 2 & 2,8 & 71 & 100 & \\
\hline
\end{tabular}


konsumsi daging mempunyai hubungan yang bermakna dengan anemia pada lansia.

Berdasarkan hasil penelitian, masih banyak lansia yang belum dapat memenuhi tingkat kecukupan protein. Persentase kejadian anemia lebih tinggi pada lansia yang mempunyai tingkat kecukupan protein kurang dibandingkan pada lansia dengan protein cukup.

Rendahnya asupan protein akan mengganggu proses pengangkutan, pembentukan dan penyimpanan zat besi. Ada tiga jenis protein yang saling terkait dalam pengangkutan dan penyimpanan zat besi dalam tubuh yaitu transferin, reseptor trasferin 1 (TfR1) dan feritin. Transferin mengangkut besi ke jaringan yang mempunyai reseptor trasferin, khususnya eritroblas yang ada di dalam sumsum tulang untuk proses pembentukan hemoglobin. Apabila proses ini terganggu akan menyebabkan anemia (Ahmed, 2010).

Menurut Besral (2007), lansia yang asupan protein kurang mempunyai risiko 77 kali mengalami anemia dibandingkan lansia yang cukup mengonsumsi protein. Hasil penelitian menunjukkan tidak ada hubungan antara tingkat kecukupan zat besi dengan anemia pada lansia. Pada penelitian ini menunjukkan adanya kecenderungan, lansia yang kecukupan zat besinya kurang persentase mengalami anemia lebih besar dibandingkan lansia yang mempunyai asupan zat besi cukup.

Penyebab lain terjadinya anemia dapat dipengaruhi oleh kualitas makanan sumber zat besi yang di konsumsi oleh seseorang. Sumber makanan besi non-heme lebih sulit absorbsi dibandingkan besi heme. Besi heme akan diabsobsi ke dalam sel mukosa sebagai kompleks porfirin utuh. Kemudian, cincin forfirin akan dipecahkan dengan enzim khusus (hemoksigenase) di sel mukosa, dan besi dapat dibebaskan. Besi non hame di dalam lambung diubah menjadi fero dan dibutuhkan vitamin $\mathrm{C}$ agar lebih mudah diabsorbsi (Lynch, dkk., 2007).

Pada duodemun akan terjadi proses penyerapan zat besi, kemudian akan dibawa melalui membran mukosa dan serosa ke dalam darah. Sebagian besar transferin akan membawa besi ke sumsum tulang yang akan digunakan untuk membuat hemoglobin. Apabila tubuh kekurangan zat besi maka proses pembentukan sel darah merah akan terganggu yang akan menyebabkan anemia (Goodnough, 2014).

Penelitian yang dilakukan Silva, dkk (2007) menjelaskan konsumsi makanan sumber zat besi yang rendah dapat mengganggu pembentukan sel darah merah sehingga kadar hemoglobin di dalam tubuh berkurang yang akhirnya dapat menyebabkan anemia. Menurut Callera (2015) ada hubungan antara tingkat kecukupan zat besi dengan kejadian anemia. Penelitian yang di lakukan di Brasil menemukan lansia yang kekurangan asupan zat besi mempunyai persentase lebih tinggi mengalami anemia dibandingkan lansia yang cukup mengonsumsi zat besi.

Berdasarkan hasil penelitian diketahui bahwa tidak ada hubungan bermakna antara kejadian anemia dengan asupan vitamin C. Data pada tabel 2 menunjukkan bahwa lansia dengan asupan vitamin C kurang, seluruhnya (100\%) mengalami anemia, sedangkan lansia dengan asupan vitamin C cukup, persentase terjadinya anemia cukup tinggi $(94,4 \%)$. Tidak adanya hubungan ini diduga karena responden jarang mengonsumsi sayur dan buah serta mengonsumsi makanan sumber vitamin $\mathrm{C}$ dengan jumlah sedikit. Apabila melihat pola makan lansia, masih banyak di antara mereka yang mengonsumsi sumber protein non heme. Oleh sebab itu, konsumsi vitamin $\mathrm{C}$ sangat penting untuk meningkatkan penyerapan besi non heme.

Vitamin $C$ dapat menghambat ekspresi hepcidin dengan mempengaruhi reseptor eryhropoietin sehingga terjadi peningkatan absorbsi zat besi (Chiu, 2012). Menurut Johnson dan Wimbley (2011), vitamin C akan mereduksikan besi feri menjadi ferro di dalam usus halus sehingga penyerapan meningkat sampai empat kali lipat dan vitamin $\mathrm{C}$ dapat memindahkan besi dari transferin di dalam plasma ke feritin hati.

Penelitian ini sejalan dengan penelitian yang dilakukan Humphreys dan Braunschweig (2011), yaitu bahwa lansia yang kurang mengonsumsi vitamin $\mathrm{C}$ banyak yang mengalami anemia, sedangkan lansia yang cukup asupan vitamin $\mathrm{C}$ kejadian anemia lebih rendah.

Hasil penelitian menunjukkan tidak ada hubungan antara tingkat kecukupan vitamin $\mathrm{B}_{12}$ dengan anemia pada lansia. Prevalensi terjadinya 
anemia pada lansia yang asupan vitamin $B_{12}$ cukup dan kurang tidak berbeda jauh. Kurangnya tingkat kecukupan vitamin $\mathrm{B}_{12}$ disebabkan kurangnya konsumsi makanan sumber protein khususnya protein hewani. Penelitian ini sejalan dengan penelitian Wong, dkk (2015) yang menunjukkan bahwa tidak ada hubungan signifikan antara tingkat kecukupan vitamin $\mathrm{B}_{12}$ dengan anemia pada lansia. Namun, dalam penelitian tersebut ada kecenderungan lansia yang anemia mempunyai kadar serum vitamin $\mathrm{B}_{12}$ lebih rendah dibandingkan lansia dengan kecukupan vitamin $\mathrm{B}_{12}$ cukup.

Pada lansia yang telah memenuhi kecukupan vitamin $B_{12}$ masih mengalami anemia dimungkinkan dapat disebabkan beberapa faktor, antara lain gangguan autoimun pada mukosa lambung yang akan menjadi tipis, dengan infiltrat sel plasma dan limfoid pada lamina propria dan dapat terjadi metaplasia usus. Selain itu, adanya infeksi Helicobacter pylori dapat mencetuskan gastritis sehingga sistem imun terganggu yang pada akhirnya akan menyebabkan seseorang lebih mudah mengalami defisiensi besi (Stabler, 2013).

Pada usia diatas 60 tahun, faktor intrinsik tidak terbentuk dan/ atau tidak disekresikan sama sekali atau disekresi dengan jumlah yang tidak dapat mencukupi untuk penyerapan vitamin $\mathrm{B}_{12}$ secara efisien. Lansia juga mengalami gasrectimy yang akan menurunkan ketersediaan faktor instrinsik sehingga dapat mengganggu proses penyerapan vitamin $\mathrm{B}_{12}$ di dalam tubuh terganggu (Sukla, 2014). Penelitian lain menyebutkan, penyebab anemia pada lansia adalah kekurangan vitamin $\mathrm{B}_{12}(10-12 \%)$, gangguan gastritis (20-50\%) dan sisanya disebabkan infeksi Helicobacter pylori (Hanna, dkk., 2009). Pada tahun 2013 dilakukan penelitian lanjutan tentang anemia di Turki yang memberikan hasil bahwa penyebab anemia defisiensi vitamin $\mathrm{B}_{12}$ disebabkan karena infeksi Helicobacter pylori (H. Pylori) sebesar 78,6\% (Ozaydin, 2013).

Berdasarkan hasil penelitian ada hubungan bermakna antara konsumsi asam folat dengan kejadian anemia pada lansia. Lansia yang cukup mengonsumsi asam folat, tidak ada yang mengalami anemia. Lansia yang mengonsumsi asam folat kurang, sebagian besar mengalami anemia.
Kekurangan asam folat pada seorang lansia dapat disebabkan oleh kurangnya keragaman makanan yang dikonsumsi, gangguan pencernaan sehingga penyerapan asam folat menjadi rendah (Fairweather, 2014). Asam folat dan vitamin $B_{12}$ tidak dapat dipisahkan, kedua zat gizi tersebut bekerja bersama-sama. Asam folat di dalam tubuh berbentuk sebagai koenzim folat (THFA), kemudian transmetilase membutuhkan vitamin $\mathrm{B}_{12}$ untuk mempercepat proses metilasi homosistein yang digunakan sebagai pembentuk metionin dan regenerasi THFA dalam sistensis DNA.

Apabila vitamin $B_{12}$ tidak cukup, asam folat akan berakumulasi dalam bentuk metil THFA dan tidak dapat mendukung pembentukan DNA, sehingga proliferase sel menurun, akibatnya terjadi perubahan dalam morfologi inti sel darah merah (Theron, 2008). Berdasarkan analisa Food Frequency Questinare (FFQ) diketahui bahwa masih banyak lansia yang mengonsumsi teh dan kopi. Hasil penelitian menunjukkan ada hubungan yang bermakna antara konsumsi teh dan konsumsi kopi dengan kejadian anemia pada lansia. Lansia yang anemia mengonsumsi kopi 7 kali perminggu dan lansia yang tidak anemia konsumsi 3 kali per minggu. Konsumsi teh pada lansia anemia $12 \mathrm{kali}$ per minggu sedangkan lansia yang tidak anemia mengonsumsi teh 5 kali per minggu.

Kopi dan teh merupakan salah satu faktor penghambat penyerapan zat besi. Teh dan kopi mengandung tanin yang dapat mengikat mineralmineral seperti zat besi. Berdasarkan hasil penelitian yang dilakukan Mascitelli (2010), mengonsumsi kopi 1 cangkir $(235 \mathrm{ml})$ perminggu dapat menurunkan kadar serum feritin.

Teh hitam mengandung senyawa polifenol yang apabila teroksidasi akan mengikat mineral seperti zat besi, zink dan kalsium. Oleh sebab itu teh hitam merupakan inhibitor yang paling kuat menghambat penyerapan zat besi. Mengonsumsi 1 cangkir teh mengandung polifenol (20-50 $\mathrm{mg}$ ) dapat menghambat penyerapan zat besi sebesar 50-70\%, sedangkan mengkonsumsi 2-3 cangkir mengandung (100-400 mg polifenol) dapat menghambat penyerapan zat besi $60-90 \%$ (Marcitelli, 2010). Penelitian yang dilakukan pada lansia di Kota Bandung menunjukkan adanya hubungan antara kebiasaan minum teh 
Tabel 3. Hubungan Pola Konsumsi Minuman yang Dapat Menghambat Penyerapan Zat Besi dengan Kejadian Anemia pada Lansia di Kelurahan Airlangga Kecamatan Gubeng Kota Surabaya

\begin{tabular}{lccccc}
\hline \multirow{2}{*}{$\begin{array}{c}\text { Frekuensi Konsumsi Minuman } \\
\text { perminggu }\end{array}$} & Anemia & $\begin{array}{c}\text { Tidak } \\
\text { Anemia }\end{array}$ & P & $\begin{array}{c}\text { Koefisien } \\
\text { Korelasi }\end{array}$ & Kesimpulan \\
\cline { 2 - 3 } Kopi & 7 kali perminggu & $\begin{array}{c}3 \text { kali } \\
\text { perminggu }\end{array}$ & 0,045 & 0,712 & $\begin{array}{l}\text { Ada hubungan signifikan } \\
\text { dengan hubungan yang } \\
\text { kuat }\end{array}$ \\
\hline Teh & $\begin{array}{c}12 \text { kali } \\
\text { perminggu }\end{array}$ & $\begin{array}{c}5 \text { kali } \\
\text { perminggu }\end{array}$ & 0,028 & 0,685 & $\begin{array}{l}\text { Ada hubungan signifikan } \\
\text { dengan hubungan yang } \\
\text { kuat }\end{array}$ \\
\hline
\end{tabular}

dengan kejadian anemia pada lansia. Berdasarkan hasil odds ratio, lansia yang mengonsumsi teh mempunyai risiko mengalami anemia sebesar 36 kali lebih besar dibandingkan lansia yang jarang dan tidak pernah mengonsumsi teh (Besral, 2007).

Penelitian Meilianingsih (2007) menunjukkan bahwa responden yang minum teh setiap hari mempunyai risiko mengalami anemia sebesar 31,64 kali dibandingkan yang jarang atau tidak minum teh. Sedang lansia yang mengonsumsi kopi setiap hari mempunyai risiko mengalami anemia sebesar 3,478 kali dibandingkan lansia yang jarang atau tidak minum kopi

\section{KESIMPULAN DAN SARAN}

Berdasarkan hasil penelitian, disimpulkan bahwa ada hubungan tingkat kecukupan asam folat, konsumsi kopi dan teh dengan status anemia pada lansia. Sebaliknya tidak ada hubungan antara tingkat kecukupan protein, zat besi, vitamin $\mathrm{C}$, dan vitamin $\mathrm{B}_{12}$ dengan anemia pada lansia. Namun ada kecenderungan anemia lebih banyak pada lansia kekurangan konsumsi zat gizi dibandingkan lansia yang cukup dalam memenuhi kecukupan zat gizi.

Hasil penelitian ini merekomendasikan perlunya dilakukan pemeriksaan kadar hemoglobin dan penyuluhan pencegahan anemia pada lansia secara berkala pada setiap posyandu lansia. Selain itu, perlu diupayakan Pemberian Makanan Tambahan (PMT) yang tinggi zat besi dan asam folat pada lansia sehingga diharapkan dapat membantu memperbaiki kondisi kesehatan lansia.

\section{DAFTAR PUSTAKA}

Ahmed, T., \& Haboubi, N. (2010). Assessment and management of nutrition in older people and its importance to health. Clin Interv Aging, 5, 207-216. Diakses dari http://www.ncbi.nlm.nih. gov/pmc/articles/PMC2920201/

Besral., Meilianingsih, Lia., Sahar, Juniati. (2007). Pengaruh Minum Teh Terhadap Kejadian Anemia Pada Usila di Kota Bandung. Makara Kesehatan, 11(1), 38-43.

Chiu PF, Ko SY, Chang CC. (2012). Vitamin $\mathrm{C}$ affects the expression of hepcidin and erythropoietin receptor in HepG2 cells. $J$ Ren Nutr, 22(3), 373-376.

Fairweather, S.J., Wawer, A.A., Gillings, R., Jennings, A., \&Myint, P.K.(2014). Iron status in the elderly. Mech Ageing Dev, 136-137(100), 22-28. doi: 10.1016/j.mad.2013.11.005

Gibson RS. (2005). Principles of Nutrition Assesment. Ed ke-2. New York: Oxford University.

Goodnough, L.T., \&Stanley L. Schrier, L.S. (2014). Evaluation and Management Of Anemia In The Elderly. Am J Hematol, 89(1), 88-96. doi: 10.1002/ajh.23598. 2015.1.10

Hanna, Susan., Lachover, Leonard., Rajarethinam, R.P. (2009). Vitamin $B_{12}$ Deficiency and Depression in the Elderly: Review and Case Report. Prim Care Companion JClin Psychiatry, 11(5), 269-270.

Humphreys, L.S., Braunschweig, C.(2011). Anemia in Postmenopausa Women: Dietary Inadequacy or Nondietary Factors?. American Dietetic Asociation, 28(3), 528-532.doi: 10.1016/j. jada.2011.01.006

Hurrellm R., Egli I. (2010). Iron bioavailability and dietary reference values. Am. J. Clin. Nutr, 91, 1461S-1467S. 
Johnson, T.D., Wimley., \& Graham, D.Y. (2011). Diagnosis and management of iron deficiency anemia in the $21^{\text {st }}$ century. Therap Adv Gastroenterol, 4(3), 177-184. doi: 10.1177/1756283X11398736. 2011.5.

Kementrian Kesehatan R.I.(2013). Hasil Riset Kesehatan Dasar (Riskesdas) 2013. Jakarta: Badan Penelitian dan Pengembangan Kesehatan

Kementrian Kesehatan R.I. (2013). Gambaran Kesehatan Lanjut Usia di Indonesia. Jakarta: Pusat Data dan Informasi Kementrian Kesehatan RI.

Lemeshow., Hosmer, D.W., Klar J., Lwanga, S.K. (1997). Besar Sampel dalam Penelitian Kesehatan . Yogyakarta: Gadjah Mada University Press.

Lynch, M.F., Graffin, I.J., Hawthrone, K.M., Chen, Z., Hamzo, M.G., Abrahams, S.A.(2007). Iron Absorption Is More Closely Related to Iron Status Than to Daily Iron Intake in 12- to 48-Mo-Old Children. American Society for Nutrition, 137(1), 88-92.

Macao. (2007). The Macao Outcome Document of the Hight Level Meeting on the Regional Review of the Implementation of the Madrid Internasional Plan of Action Ageing: 3-9.

Mascitelli, L., \& Goldstein, M.R. (2010). Inhibition of iron absorption by polyphenols as an anticancer mechanism. QJMed2011, 104, 459-461. doi:10.1093/qjmed/hcq239.2010.12.015

Meilianingsih., lia., (2007). Pengaruh Minum Teh Terhadap Kejadian Anemia Pada Usila di Kota Bandung. Makara Kesehatan. 11(1), 38-43.
Nakashima, A.T., Moraes, A.C., Auler, F., \& Peralta, R.M. (2012). Anemia prevalence and its determinants in Brazilian institutionalized elderly. Nutrition, 28 (5) , 640-643. Diakses dari Nutrition Journal.

Ozaydin, N., Turkyilmaz, S. A., \& Cali, S. (2013). Prevalence and risk factors of helico-bacter in Turkey: A nationally-representative, crosssectional, screnning with the 13C-Urea breath test.BMC Public Health, 13, 1215.

Ping, Y., \& Xiaohua, W. (2012). Risk factors for accidental falls in the elderly and intervention strategy. Journal of Medical Colleges of PLA. Diakses dari http://www.elsevier.com/locate/ jmcpla

Silva, D.G., Priore, S.E., Franceschini, S.C.C (2007). Fatores de risc pra anemia em lactente atendidos nos servious publicos de saude: a Importancia das prakticas alimentares e da suplementaca com ferro. Journal of pediatrics, 83, 149-156.

Stabler, S.P. (2013). Vitamin B12 Deficiency. The new england journa l o fmedicine, 368, 149-60. DOI: 10.1056/NEJMcp1113996. 2013.01.010

Thankachan. (2008). Iron Absorbtion in Young Women: the Interaction of Iron Status With the Influence of Tea and Ascorbic Acid. The American Jounal of Clinical Nutrition, 87, 881.

Wong, C.W.,Ip, C.P. Leung, C.S. Leung, J.N. Cheng, C.Y. Siu. (2015). Vitamin B12 deficiency in the institutionalized elderly: A regional study. Experimental Gerontology, 69, 221-225. 